\title{
Mencari Bentuk Kedaulatan dalam UUD Tahun 1945
}

\author{
Rudy \\ Bagian Hukum Tata Negara Fakultas Hukum Universitas Lampung \\ Email : rudy.1981@fh.unila.ac.id
}

\begin{abstract}
Abstrak
Tulisan ini bertujuan untuk melacak bentuk-bentuk kedaulatan dalam UUD 1945. Untuk mencapai tujuan dari penulisan ini, akan diuraikan teori-teori kedaulatan sebagai alat analisis terhadap pembukaan dan batang tubuh UUD 1945. Setelah menguraikan teori-teori kedaulatan, pembukaan dan batang UUD 1945 dibedah secara substansi untuk melacak bentuk-bentuk kedaulatan dalam UUD 1945. Pembukaan UUD 1945 memberikan bentuk-bentuk kedaulatan yang dinyatakan dengan jelas dalam kalimat-kalimat seperti "Atas berkat rahmat Allah yang Maha Kuasa" dan "Negara Republik Indonesia yang berkedaulatan rakyat". Oleh karena itu dilihat dari pembukaan UUD 1945, bentuk kedaulatan rakyat dan kedaulatan tuhan tercermin jelas bagi dalam Pembukaan UUD 1945. Ketentuan UUD 1945 dalam batang tubuhnya terutama dalam hal pembagian kekuasaan menegaskan dasar kedaulatan rakyat yang dianut oleh konstitusi kita. Dalam konteks ini bentuk kedaulatan rakyat harus menjadi acuan dalam membaca konstitusi kita. Dalam hubungannya dengan kedaulatan rakyat, konstitusi kita menyandingkannya dengan negara hukum sehingga sangatlah tepat jika NKRI mempunyai dasar kedaulatan rakyat dalam koridor kedaulatan hukum. Konstitusi dan kedaulatan rakyat sangat berkaitan erat karena hakikinya konstitusi merupakan suatu bentuk hukum dari konsepsi kedaulatan rakyat. Dalam konsep ini, kedudukan konstitusi dalam suatu negara hukum merupakan hal yang sangat penting karena hukum akan selalu berdasarkan konstitusi sebagai hukum tertinggi dalam suatu negara. Kedaulatan rakyat, konstitusionalisme, dan kedaulatan hukum kemudian melahirkan apa yang disebut sebagai negara hukum berdasar pada demokrasi konstitusional atau constitutional democracy. Demokrasi konstitusional ini pun mempunyai dasar kedaulatan tuhan dalam ruh-nya.
\end{abstract}

Kata kunci : kedaulatan dan UUD Tahun 1945

\section{Pendahuluan}

Kedaulatan, bahasa Latinnya supremus, bahasa Inggrisnya sovereignty, bahasa Italianya disebut sovranita yang berarti tertinggi. Kedaulatan dalam bahasa Arab daulah, daulat yang artinya kekuasaan. Kedaulatan dari berbagai bahasa itu dapat diartikan sebagai wewenang satu kesatuan politik. ${ }^{1}$

\footnotetext{
1 Jimly Asshidiqie, Pokok-Pokok Hukum Tata Negara Indonesia: Pasca Reformasi,
}

Kedaulatan adalah konsep mengenai kekuasaan tertinggi dalam negara. Kedaulatan menurut Jack $\mathrm{H}$. Nagel sebagaimana dikutip Jimly Asshiddiqie ${ }^{2}$ mempunyai dua arti penting meliputi lingkup kekuasaan dan jangkauan kekuasaan. Lingkup

(Jakarta: PT Bhuana Ilmu Populer, 2008), hlm. 158.

2 Jimly Asshiddiqie, Gagasan Kedaulatan Rakyat dalam Konstitusi dan Pelaksanaannya di Indonesia, (Jakarta: PT Ichtiar Baru Van Hoeve, 1994), hlm. 9. 
kedaulatan mencakup aktivitas atau kegiatan dalam fungsi kedaulatan, sedangkan jangkauan kedaulatan berkaitan dengan siapa yang menjadi subyek dan pemegang kedaulatan.

Konsep kedaulatan dalam alam pikiran modern pertama kali dikemukakan oleh Jean Bodin. Selanjutnya, konsep ini terus berkembang dan tercatat beberapa nama penting disinggung setiap kali berbicara tentang Kedaulatan, yaitu Thomas Hobbes, George Jellinek, John Locke dan Jean Jacques Rousseau. Konsep tersebut dikembangkan sebagai reaksi atas kekuasaan yang terlalu besar dari kaum penguasa negara dan gereja, khusus pada abad pertengahan di Eropa.

Kedaulatan menurut Jean Bodin mempunyai 3 sifat pokok yaitu: ${ }^{3}$

1. Absolute atau Absolut. Artinya kedaulatan tersebut tidak ada terbatas, sebab apabila terbatas maka sifat tertinggi akan lenyap.

2. Indivisible atau tidak terbagi. artinya kedaulatan itu tidak berasal dari kekuasaan lain yang lebih tinggi dan hanya satusatunya kekuasaan yang tertinggi;

3. Permanent atau Abadi. Permanen artinya kedaulatan yang tetap ada selama negara itu masih berdiri;

Jimly Asshidiq ${ }^{4}$ menyimpulkan bahwa kedaulatan adalah sebagai kekuasaan yang tertinggi dalam suatu negara atau kesatuan yang tidak terletak dibawah kekuasaaan lain.

\footnotetext{
${ }^{3}$ Menurut Bodin, setiap entitas politik yang berdaulat mempunyai otoritas yang absolute, indivisible, and permanent, lihat Scott Gordon, Controlling the state: constitutionalism from ancient Athens to today, (Harvard University Press, paperback edition, 2002), hlm. 22

${ }^{4}$ Ibid.
}

Di Indonesia, perdebatan mengenai gagasan kedaulatan rakyat sudah mengemuka jauh sebelum penyusunan UUD 1945. Baik Soekarno melalui majalah Fikiran Ra'jat dan Soeloeh Indonesia Moeda, maupun Hatta melalui majalah Daoelat Ra'jat sudah mengemukakan gagasan kedaulatan rakyat yang meliputi demokrasi politik dan demokrasi ekonomi. 5 Pada perkembangannya, prinsip kedaulatan rakyat inilah yang kemudian melahirkan konsep demokrasi yang menempatkan rakyat sebagai pemegang kedaulatan. Dengan berkembangnya negara dan dunia, prinsip kedaulatan rakyat ini kemudian terwujud dalam sistem demokrasi perwakilan.

Moh. Kusnardi dan Harmaily Ibrahim mengemukakan, rakyatlah yang dianggap sebagai pemilik dan pemegang kekuasaan tertinggi dalam suatu negara. ${ }^{6}$ Sebagai pemilik dan pemegang kekuasaan, rakyat menentukan corak dan cara pemerintahan diselenggarakan, serta menentukan tujuan yang hendak dicapai negara. ${ }^{7}$ Dalam UUD 1945 , kedaulatan rakyat dilaksanakan melalui sistem perwakilan (representation). Jimly Asshidiqie menyatakan bahwa kedaulatan rakyat dengan sistem perwakilan atau demokrasi biasa juga disebut sistem demokrasi perwakilan (representative democracy) atau

\footnotetext{
5 Lihat Jimly Asshiddiqie, Gagasan Kedaulatan... Op.Cit., hlm. 2.

${ }^{6}$ Moh. Kusnardi dan Harmaily Ibrahim, Pengantar Hukum Tata Negara Indonesia, (Jakarta: PSHTN FHUI, 1983), hal. 328.

${ }^{7}$ Jimly Asshidiqie, Pengantar Ilmu Hukum Tata Negara Indonesia, (Jakarta: Sekretariat Jenderal dan Kepaniteraan Mahkamah konstitusi, 2006), hlm. 168.
} 
demokrasi tidak langsung (indirect democracy). ${ }^{8}$

Sementara itu Hatta yang mempunyai pandangan bahwa kedaulatan rakyat berarti bahwa kekuasaan untuk mengatur pemerintahan dan negara ada pada rakyat, rakyat yang berdaulat, berkuasa untuk menentukan cara bagaimana ia harus diperintah. Tetapi putusan rakyat yang menjadi peraturan pemerintah bagi orang semuanya ialah keputusan yang ditetapkan dengan cara mufakat dalam suatu perundingan yang teratur bentuk dan jalannya. ${ }^{9}$

Dalam konteks kedaulatan, tulisan ini bertujuan untuk melacak bentuk-bentuk kedaulatan dalam UUD 1945. Untuk mencapai tujuan dari penulisan ini, akan diuraikan teori-teori kedaulatan sebagai alat analisis terhadap pembukaan dan batang tubuh UUD 1945.

\section{Pembahasan}

\subsection{Teori Kedaulatan}

Teori kedaulatan pada umumnya terbagi menjadi 5 teori besar yaitu teori kedaulatan tuhan, teori kedaulatan raja, teori kedaulatan negara, teori kedaulatan rakyat, dan teori kedaulatan hukum. Dalam bagian ini akan diuraikan satu persatu teori-teori tersebut untuk keperluan analisis terhadap UUD 1945.

\section{Teori Kedaulatan Tuhan}

Teori ini berkembang pada abad XV atau abad pertengahan di mana pada saat itu muncul dua

\footnotetext{
${ }^{8}$ Ibid, hal. 328.

9 Zulfikri Suleman, Demokrasi untuk Indonesia: Pemikiran Politik Bung Hatta, (Jakarta: Penerbit Buku Kompas, 2010), hlm. 12-13.
}

organisasi kekuasaan yaitu organisasi kekuasaan Negara yang dipimpin oleh Raja, dan organisasi kekuasaan gereja yang dipimpin oleh Paus. Kedua organisasi ini memiliki ideologi yang sungguh berbeda akan tetapi kedua organisasi ini percaya dan mengakui bahwa kekuasaan tertinggi berada di tangan Tuhan. Hanya saja yang menjadi pokok permasalahannya adalah siapa yang menjadi wakil Tuhan di dunia. Oleh sebab itu kedua organisasi ini saling memegang teguh masing-masing ideologi mereka yang mana dari organisasi kekuasaan Negara memandang bahwa yang menjadi wakil Tuhan di dunia adalah Raja sedangkan dari organisasi kekuasaan gereja berasumsi bahwa yang menjadi wakil Tuhan adalah Paus. Hal ini terlihat jelas betapa bertolak belakangnya kedua organisasi kekuasaan tersebut.

Salah satu tokoh dari kedaulatan tuhan adalah Thomas Aquinas yang terkenal lewat karyanya Summa Theologia. Thomas Aquinas dalam karyanya menyatakan bahwa meskipun kedaulatan tidak terikat oleh daya paksa hukum, tetapi kedaulatan tunduk pada hukum tuhan dan hukum alam dengan sanksi yang dipaksakan oleh Tuhan. ${ }^{10}$

\section{Teori Kedaulatan Raja}

Ajaran kedaulatan raja beranggapan bahwa rajalah yang memegang kekuasaan tertinggi negara. Pandangan ini muncul terutama setelah periode sekularisasi negara dan hukum di Eropa. Raja dalam hal ini bahkan dianggap

\footnotetext{
${ }^{10}$ Brian Z Tamanaha, on The Rule of law, (Cambridge University Press, 2004), hlm. 19.
} 
sebagai pemimpin suci yang dipilih termasuk sebagai pemegang kedaulatan untuk menciptakan hukum dan sekaligus melaksanakannya. ${ }^{11}$

Padmo Wahjono menyatakan kedaulatan raja dalam hal ini dapat digabungkan dengan teori pembenaran negara yang menimbulkan kekuasaan mutlak pada raja. Misalnya, teori-teori kekuasaan jasmani atau teori-teori perjanjian dari pada Thomas Hobbe, ajaran ini sampai pada puncaknya pada ajaran yang berslogan 'i'etat cest moi". ${ }^{12}$

Jika ajaran kedaulatan raja pada mulanya dapat diterima oleh rakyat maka lama-kelamaan ia ditolak bahkan dibenci oleh karena sifat raja yang sewenang-wenang. Rakyat tidak dapat tempat perlindungan lagi dari raja dan disana sini rakyat mulai sadar bahwa keadaan semacam itu tidak dapat dipertahankan lagi. Sejak itu mulailah muncul ajaran-ajaran baru yang memberi jaminan kepada rakyat yang sewajarnya. Diantaranya adalah ajaran dari monarchomachen hendak membatasi kekuasaan raja. Baru kemudian muncul ajaran kedaulatan rakyat dari Rousseau yang disusul dengan pemberontakan rakyat. ${ }^{13}$

\section{Teori Kedaulatan Negara.}

Teori ini berawal dari tindakan Raja yang merasa berkuasa untuk menetapkan agama yang harus di

\footnotetext{
${ }^{11}$ Jimly Asshiddiqie, Gagasan Kedaulatan... Op.Cit., hlm. 10.

${ }^{12}$ Padmo Wahjono, Ilmu Negara, (Jakarta: Indo Hill co., 1996), hlm. 155

${ }^{13}$ Moh. Koesnardi, dan Bintan R. Saragih, Ilmu Negara, (Jakarta: Perintis Press, 1985), hlm. 107
}

anut oleh rakyatnya, karena Raja berasumsi bahwa ia tidak bertanggung jawab kepada selain Tuhan. Sehingga rakyat yang tadinya berasumsi sama dengan Raja yaitu hukum yang harus di taati adalah hukum Tuhan, sekarang justru berganti haluan yaitu bahwa negaralah yang harus ditaati. Negaralah satu-satunya yang berwenang menciptakan dan menetapkan hukum. Di luar Negara tidak ada satu orang pun yang berwenang menetapkan hukum. Dan dari sinilah awal dari teori kedaulatan Negara, di mana Negara adalah satu-satunya sumber hukum yang memiliki kekuasaan tertinggi atau kedaulatan. Tokoh dari paham Kedaulatan Negara adalah Jellinek, Jean Bodin, dan Thomas Hobbes.

Menurut Jellinek, hukum adalah penjelmaan kehendak negara, jadi hukum diciptakan oleh negara, dengan demikian satu-satunya sumber hukum adalah negara. Masih menurut Jellinek, adat kebiasaan dapat menjadi hukum, apabila negara telah menetapkan sebagai hukum. ${ }^{14}$

Thomas Hobbes dalam mengemukakan teorinya berangkat dari perjanjian antar individu untuk melahirkan suatu negara. Perjanjian antar individu yang terkenal dengan teori kontrak negara ini yang membedakan pandangan antara Hobbes dengan Bodin. Dalam perjanjian itu, para individu yang selalu bertikai itu menyerahkan semua hak mereka kepada negara. Ini berarti perjanjian yang dilakukan bukan antara individu dengan negara, sebab negara adalah buah dari perjanjian itu, dan tidak mempunyai

\footnotetext{
14 Soehino, Ilmu Negara, (Liberty, Yogyakarta, 2000), hlm 155.
} 
kewajiban apapun terhadap para individu. ${ }^{15}$

Paham ini melahirkan absolutisme negara, dan absolutisme negara ini diperkuat dengan teori kontrak negara tersebut. Hobbes bukan tidak menyadari jika absolutisme ini dapat saja disalahgunakan oleh penguasa. Untuk itu ia menyatakan penguasa masih mempunyai kewajiban untuk bertanggung jawab kepada Tuhan, karena kekuasaan yang diperolehnya berasal dari Tuhan, bukan dari masyarakat. Landasan moral inilah satu-satunya pembatas yang dapat menghindarkan negara dari kesewenang-wenangan. ${ }^{16}$

\section{Teori Kedaulatan Rakyat}

$\begin{array}{lrr}\text { Teori kedaulatan } & \text { rakyat } \\ \text { bertolak dari persepsi } & \text { bahwa } \\ \text { sesungguhnya rakyatlah } & \text { yang } \\ \text { memegang } & \text { kekuasaan } & \text { tertingoi }\end{array}$
megang kekuasaan tertinggi dalam negara bukan penguasa. Tokoh-tokoh teori kedaulatan rakyat adalah John Locke, Montesquie, dan Jean Jacque Rosseau. Teori kedaulatan rakyat lahir sebagai reaksi dari teori kedaulatan raja dan teori kedaulatan negara yang melahirkan absolutisme karena penguasa cenderung mempertahankan dan memperluas kekuasaannya.

Kekuasaan negara dalam konteks teori kedaulatan negara tidaklah tak terbatas. Kekuasaan yang dimiliki negara datang dari para individu yang membuat perjanjian, bukan dari Tuhan seperti teori Hobbes. Jika Hobbes berpendapat bahwa individu-individu senantiasa bertikai, Locke sebaliknya mengatakan bahwa manusia itu pada

\footnotetext{
${ }^{15}$ Scott Gordon, op. cit., hlm. 25

${ }^{16}$ Ibid.
}

awalnya hidup dalam kedamaian. Situasi ini baru berubah setelah manusia mulai diperdayai oleh materi, termasuk masalah tanah. Untuk melindungi hak milik inilah yang membuat para individu bersepakat mendirikan negara. Hak milik ini meliputi pula hak-hak asasi manusia yang paling utama, seperti hak untuk hidup dan kebebasan. Para individu yang mengadakan perjanjian tersebut kemudian menyerahkan hak-haknya kepada negara, dan sebagai konsekuensinya, pembatasan kekuasaan negara harus dicantumkan dalam suatu naskah dasar perjanjian masyarakat yang sering disebut sebagai legez fundamentalis. Legez fundamentalis ini yang kemudian berkembang pengertiannya menjadi konstitusi.

Sementara itu, Jean Jacques Rousseau merupakan ahli hukum tata negara yang menentang keras absolutisme negara. Menurutnya: ${ }^{17}$ In the ideal social collectivity, the opinions, interests, and preferences of individuals are amalgamated into the "general will," which is the only legitimate sovereign authoritylegitimate because it contains, and transcends, the wills of the individual members. In such a regime, laws that are in accordance with the general will are not coercive, and they are never unjust, for no one can coerce or be unjust to one self.

Setiap individu memiliki kehendaknya sendiri, tetapi di sisi lain juga ada kepentingan para individu untuk menjaga hubungan sosial. Hal terakhir ini disebut kehendak umum atau general will (volonte generale). Tugas negara adalah menjalankan kehendak umum

\footnotetext{
${ }^{17}$ Scott Gordon, op. cit., hlm. 31
} 
dari rakyat itu. Ini berarti kehendak rakyat identik dengan kehendak negara. Rakyat yang memiliki negara, bukan penguasa. Rakyatlah pemilik kedaulatan.

Selain volonte generale terdapat pula volonte de tous yang menurut Rosseau hanya dipergunakan oleh rakyat seluruhnya sekali saja waktu Negara hendak dibentuk melalui perjanjian masyarakat. Maksud volunte de tous ini untuk memberikan dasar agar supaya Negara dapat berdiri abadi, karena ini merupakan kebulatan kehendak, dan jika Negara itu sudah berdiri, pernyataan setuju tidak bisa ditarik kembali. Untuk selanjutnya volunte de tous ini sudah tidak dipakai lagi, karena jika setiap keputusan harus dilakukan dengan suara bulat, maka roda pemerintahan tidak dapat berjalan. ${ }^{18}$

Meskipun demikian, Rosseau tidak menyetujui jika penyerahan kewenangan rakyat pada penguasa atau negara adalah wujud dari penyerahan hak dan kebebasan belaka. Kontrak sosial bermakna penyerahan untuk mewujudkan kebebasan itu sendiri. Kontrak sosial menghidupkan tatanan pemerintahan dan struktur kenegaraan yang teratur sekaligus menepis kegundahan filosofis yang mendera rakyat di era state of nature. ${ }^{19}$

\section{Teori Kedaulatan Hukum}

Teori ini menyatakan bahwa yang memiliki kekuasaan tertinggi dalam suatu negara ialah hukum,

\footnotetext{
18 Lihat Moh. Kusnardi dan Harmaily Ibrahim, Hukum Tata Negara Indonesia, Ctk Ketujuh, (Jakarta: Pusat Studi Hukum Tata Negara FH UI dan CV Sinar Bakti, 1988), hlm. 126.

${ }^{19}$ Fahri Hamzah, Negara Pasar dan Rakyat, (Faham Indonesia, 2010), hlm. 26-27.
}

karena itu baik raja, penguasa, dan rakyat serta negara sendiri tunduk terhadap hukum. Hugo Krabbe sebagai salah seorang ahli yang mempelopori aliran ini berpendapat bahwa negara sudah seharusnya negara hukum (rechstaat) dan setiap tindakan negara harus didasarkan pada hukum atau harus dapat dipertanggungjawabkan pada hukum. ${ }^{20}$

Menurut Krabbe yang menjadi sumber hukum adalah rasa hukum, yang terdapat di masyarakat. Rasa hukum ini dalam bentuknya masih sederhana atau primitif, dan dalam bentuknya yang telah maju disebut kesadaran hukum Kalau diperhatikan lebih jauh ke belakang, konsep kedaulatan yang didasarkan pada hukum ini adalah suatu reaksi atas prinsip ajaran teori kedaulatan negara. $^{21}$

\subsection{Pembukaan UUD 1945}

\section{PEMBUKAAN \\ ( P r e a m b u l e )}

Bahwa sesungguhnya Kemerdekaan itu ialah hak segala bangsa dan oleh sebab itu, maka penjajahan di atas dunia harus dihapuskan, karena tidak sesuai dengan perikemanusiaan dan peri-keadilan.

Dan perjuangan pergerakan kemerdekaan Indonesia telah sampailah kepada saat yang berbahagia dengan selamat sentausa mengantarkan rakyat Indonesia ke depan pintu gerbang kemerdekaan Negara Indonesia, yang merdeka, bersatu, berdaulat, adil dan makmur.

Atas berkat rakhmat Allah Yang Maha Kuasa dan dengan didorongkan oleh keinginan luhur,

\footnotetext{
${ }^{20}$ Soehino, op. cit., hlm. 156-158

${ }^{21}$ Ibid.
} 
supaya berkehidupan kebangsaan yang bebas, maka rakyat Indonesia menyatakan dengan ini kemerdekaannya.

Kemudian daripada itu untuk membentuk suatu Pemerintah Negara Indonesia yang melindungi segenap bangsa Indonesia dan seluruh tumpah darah Indonesia dan untuk memajukan kesejahteraan umum, mencerdaskan kehidupan bangsa, dan ikut melaksanakan ketertiban dunia yang berdasarkan kemerdekaan, perdamaian abadi dan keadilan sosial, maka disusunlah Kemerdekaan Kebangsaan Indonesia itu dalam suatu Undang-Undang Dasar Negara Indonesia, yang terbentuk dalam suatu susunan Negara Republik Indonesia yang berkedaulatan rakyat dengan berdasar kepada Ketuhanan Yang
Maha Esa, Kemanusiaan yang adil dan beradab, Persatuan Indonesia dan Kerakyatan yang dipimpin oleh hikmat kebijaksanaan dalam Permusyawaratan/Perwakilan, serta dengan mewujudkan suatu Keadilan sosial bagi seluruh rakyat Indonesia.

Pembukaan UUD 1945 memberikan bentuk-bentuk kedaulatan yang dinyatakan dengan jelas dalam kalimat-kalimat seperti "Atas berkat rahmat Allah yang Maha Kuasa" dan "Negara Republik Indonesia yang berkedaulatan rakyat". Oleh karena itu dilihat dari pembukaan UUD 1945, bentuk kedaulatan rakyat dan kedaulatan tuhan tercermin jelas bagi dalam Pembukaan UUD 1945.

\subsection{Batang Tubuh UUD 1945}

\section{BAB I \\ BENTUK DAN KEDAULATAN}

\section{Pasal 1}

(1) Negara Indonesia ialah Negara Kesatuan, yang berbentuk Republik.

(2) Kedaulatan berada di tangan rakyat dan dilaksanakan menurut UndangUndang Dasar.***)

(3) Negara Indonesia adalah negara hukum. ***)

\section{BAB II}

\section{MAJELIS PERMUSYAWARATAN RAKYAT}

\section{Pasal 2}

(1) Majelis Permusyawaratan Rakyat terdiri atas anggota Dewan Perwakilan Rakyat dan anggota Dewan Perwakilan Daerah yang dipilih melalui pemilihan umum dan diatur lebih lanjut dengan undang-undang.****)

\section{Pasal 6A}

(1) Presiden dan Wakil Presiden dipilih dalam satu pasangan secara langsung oleh rakyat.***).

\section{BAB VII \\ DEWAN PERWAKILAN RAKYAT}

\section{Pasal 19}

(1) Anggota Dewan Perwakilan Rakyat dipilih melalui pemilihan umum. **)

(2) Susunan Dewan Perwakilan Rakyat diatur dengan undang-undang. **) 
(3) Dewan Perwakilan Rakyat bersidang sedikitnya sekali dalam setahun. **)

Ketentuan UUD 1945 dalam batang tubuhnya terutama dalam hal pembagian kekuasaan menegaskan dasar kedaulatan rakyat yang dianut oleh konstitusi kita. Dalam konteks ini bentuk kedaulatan rakyat harus menjadi acuan dalam membaca konstitusi kita. Dalam hubungannya dengan kedaulatan rakyat, konstitusi kita menyandingkannya dengan negara hukum sehingga sangatlah tepat jika NKRI mempunyai dasar kedaulatan rakyat dalam koridor kedaulatan hukum.

\section{Simpulan}

Konstitusi dan kedaulatan rakyat sangat berkaitan erat karena hakikinya konstitusi merupakan suatu bentuk hukum dari konsepsi kedaulatan rakyat. Dalam perkembangannya rakyat menyelenggarakan kedaulatan yang dimilikilinya melalui wakilnya. Di sisi lain, teori kedaulatan hukum menyatakan bahwa yang memiliki kekuasaan tertinggi dalam suatu negara ialah hukum, karena itu baik raja, penguasa, dan rakyat serta negara sendiri tunduk terhadap hukum. Konsep kedaulatan ini kemudian melahirkan negara hukum yang mempunyai unsur utama bahwa setiap tindakan negara harus didasarkan pada hukum atau harus dapat dipertanggungjawabkan pada hukum.

Dalam konsep ini, kedudukan konstitusi dalam suatu negara hukum merupakan hal yang sangat penting karena hukum akan selalu berdasarkan konstitusi sebagai hukum tertinggi dalam suatu negara. Dengan kata lain, segala tindakan atau perilaku seseorang maupun penguasa berupa kebijakan yang tidak didasarkan atau menyimpang konstitusi, berarti tindakan tersebut adalah inkonstitusional.

Dari perspektif negara sebagai organisasi kekuasaan, maka konstitusi menetapkan bagaimana kekuasaan dibagi antara beberapa lembaga kenegaraan, misalnya antara badan legislatif, eksekutif, dan yudikatif. Konstitusi menentukan cara-cara bagaimana pusat-pusat kekuasaan ini bekerja sama dan menyesuaikan diri satu sama lain, dan merekam hubungan-hubungan kekuasaan dalam suatu negara. ${ }^{22}$ Kedaulatan rakyat, konstitusionalisme, dan kedaulatan hukum (negara hukum) kemudian melahirkan apa yang disebut sebagai negara hukum berdasar pada demokrasi konstitusional atau constitutional democracy. Demokrasi konstitusional ini pun mempunyai dasar kedaulatan tuhan dalam ruh-nya.

\section{DAFTAR PUSTAKA}

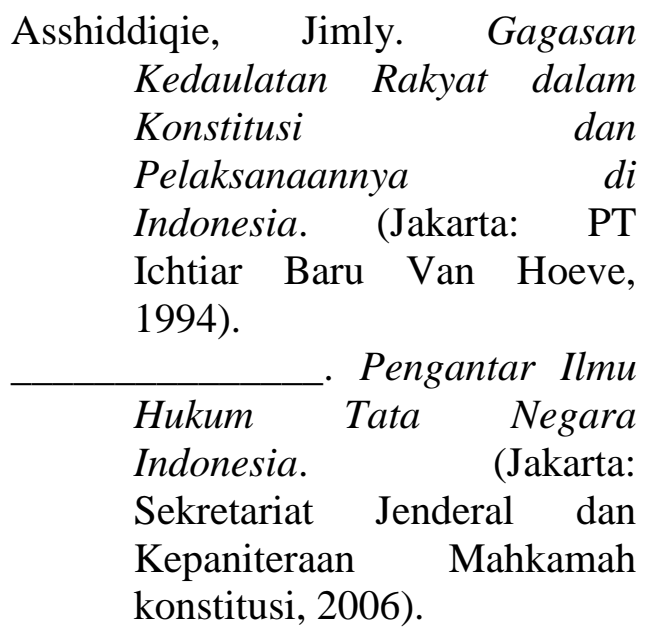

22 Dahlan Thaib, Jazim Hamidi dan Ni'matul Huda, Teori dan Hukum Konstitusi, (Jakarta: PT Raja grafindo, 1999), hlm. 9. 


Hukum Pata Pokok-Pokok
Indonesia: Pasca Reformasi.
(Jakarta: PT Bhuana Ilmu
Populer, 2008).

Gordon, Scott. Controlling the State:

Constitutionalism from

Ancient Athens to Today.

(Harvard University Press, paperback edition, 2002).

Tamanaha, Brian Z. on The Rule of Law. (Cambridge University Press, 2004).

Wahjono, Padmo. Ilmu Negara. (Jakarta: Indo Hill co., 1996).

Koesnardi, Moh. dan Bintan R. Saragih, Ilmu Negara, (Jakarta: Perintis Press, 1985).

Soehino. Ilmu Negara. (Liberty, Yogyakarta, 2000).

Kusnardi Moh. dan Harmaily Ibrahim. Hukum Tata Negara Indonesia, Ctk Ketujuh. (Jakarta: Pusat Studi Hukum Tata Negara FH UI dan CV Sinar Bakti, 1988).

Hamzah, Fahri. Negara Pasar dan Rakyat. (Faham Indonesia, 2010).

Suleman, Zulfikri. Demokrasi untuk Indonesia: Pemikiran Politik Bung Hatta. (Jakarta: Penerbit Buku Kompas, 2010.

Thaib, Dahlan, Jazim Hamidi dan Ni'matul Huda. Teori dan Hukum Konstitusi. (Jakarta: PT Raja grafindo, 1999). 